\title{
OBJECTIFICATION OF MODULUS ELASTICITY OF FOAM CONCRETE POROFLOW 17-5 ON THE SUB- BASE LAYER
}

Matej HÁJEK ${ }^{1, *}$, Martin DECKÝ ${ }^{2}$, Walter SCHERFEL ${ }^{3}$

${ }^{1}$ Department of Highway Engineering, Faculty of Civil Engineering, University of Žilina, Univerzitná 8215/1, 01026 Žilina, Slovakia.

2 Department of Highway Engineering, Faculty of Civil Engineering, University of Žilina, Univerzitná 8215/1, 01026 Žilina, Slovakia.

${ }^{3}$ Iwtech s.r.o., Mateja Bela 2504/17, 91108 Trenčín, Slovakia.

corresponding author: matej.hajek@fstav.uniza.sk.

\section{Abstract}

Principles of sustainable development create the need to develop new building materials. Foam concrete is a type of lightweight concrete that has many advantages compared to conventional building materials, for example low density and thermal insulation characteristics. With current development level, any negatively influencing material features are constantly eliminated as well. This paper is dealing with substitution of hydraulically bound mixtures by cement foam concrete Poroflow 17-5. The executed assessment is according to the methodology of assessing the existing asphalt pavements in Slovak Republic. The ex post calculation was used to estimate modulus range for Poroflow $17-5$ based on the results of static load tests conducted using the Testing Experiment Equipment.
\end{abstract}

\section{Keywords:}

Foam concrete;

Modulus of elasticity;

Static load test;

Dynamic load tests;

Test experiment equipment.

\section{The use, the main advantages, and examples of use of lightweight concrete}

Marcus Vitruvius Pollio (80/70 BC to $15 \mathrm{BC}$ ), the commander of Civil Engineers (praefectus fabrum) in Caesar's army and in time of peace a civil architect, recommended to use hydraulic binder for concrete in buildings in ratio $1: 3$ of lime and pozzolan (Italian: pozzolana - fine arenaceous volcanic ash, volcanic silicate) and the ratio of $1: 2$ for one used under the river or sea surface [1]. The artificial harbor in Caecareji was one of the bravest as well as the greatest ancient engineering structures according to [2]. Herodotus the Great, King of Judea in $37-4$ BC, founded this town. Archaeological research from 1980 discovered the lightweight concrete was used to build gridiron northern breakwater piers in the dimensions of $11.5 \times 15 \times 2.4 \mathrm{~m}$. Following analysis of this concrete confirmed Vitruvius's recommendations to be perfectly accurate in terms of lime to pozzolana $1: 2$ ratio. This ancient concrete, while dry, could easily float for a certain time and because of that, it had to be supported using double wooden formwork.

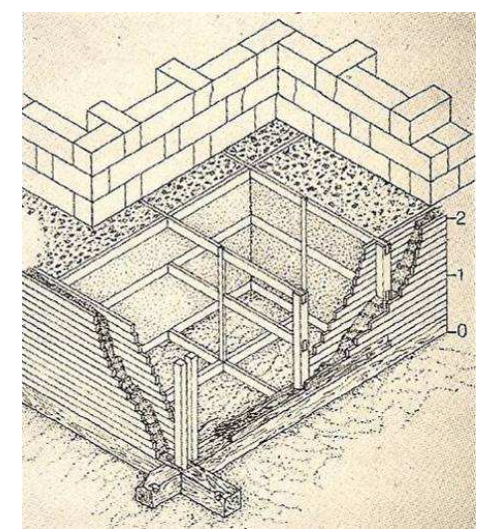

Fig. 1: The formwork used to "transport" lightweight concrete to a destination in the sea during the construction of the artificial harbor at Caecareji [2]. 
As the concrete settled and absorbed water, it became much heavier and then it was dropped to its place to create the solid formwork which, afterwards, was filled with even more concrete to create huge blocks [2].

Today lightweight concrete (foam concrete) is a mixture of binder (usually cement), water, admixtures, additives and technical foam what makes concrete a building material with good mechanical strength, low thermal conductivity and with simple, yet highly technologically demanding processing. The function of filler in the mixture is to fulfil the air bubbles, making it appropriate to produce foam concrete directly on the construction site using special technological equipment intended for such production. If the foam concrete was mixed outside the site and transported there by mobile concrete mixers, it would cause significant decrease of its volume followed by increasing costs.

The main advantages of foam concrete structures include:

- Simple and quick pouring - with such pouring it is possible to produce and implement the installation of 400 - 600 cubic meters per day and to significantly reduce construction time and costs.

- Complete filling of cavities and pores without compaction - the advantage of foam concrete is that all cavities get filled, which means that it is also partly self-levelling.

- Good absorption properties - foam concrete has a fine cell structure, which allows it to absorb kinetic energy during compression or settlement of upper construction.

- Low failure rate - in contrast to some of the synthetically lightened materials, the foam concrete is not susceptible to failure due to the presence of hydrocarbons, bacteria or fungi.

- Environmentally friendly - the usage and manufacturing of the foam concrete directly on the construction site with a dosing device means less traffic disturbing and less manipulation on site. Recycling is also very easy and energy efficient.

- Wide range of densities - the usual range of bulk density is from 300 to $1600 \mathrm{~kg} / \mathrm{m}^{3}$.

According to [4], foam concrete have been used in highway construction in the United Kingdom (UK) since 1970, yet it took about 10 years for foam concrete to become competitive as well as recognized building material. Internet sources claim that the greatest construction suppliers using foam concrete technology in the UK are the Foam Concrete Ltd. and The Pump Engineering Ltd. These companies are behind construction of following buildings:
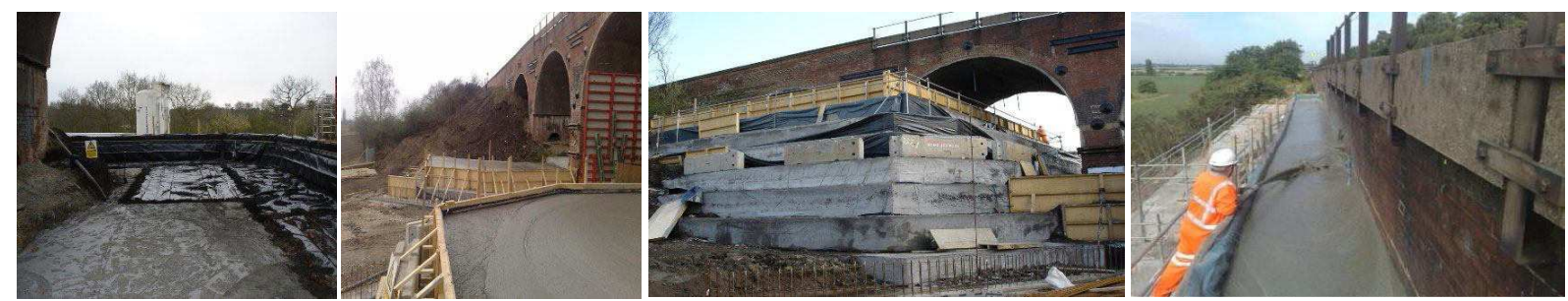

Fig. 2: Views of preparation of the underlay, a poured layer of foam concrete, the pyramidal formwork and application of the last layer of foam concrete.

Foam concrete was used as a base material for roads in newly built Hertfordshire (UK) industrial zone. The original subbase consisted of peat that caused numerous floods in the area in combination with high phreatic surface. It was necessary to implement drainage before and during construction. It was not possible to use common structure of the road because repeating wetting and drying of individual construction layers would subsequently damage already finished road structure [4].
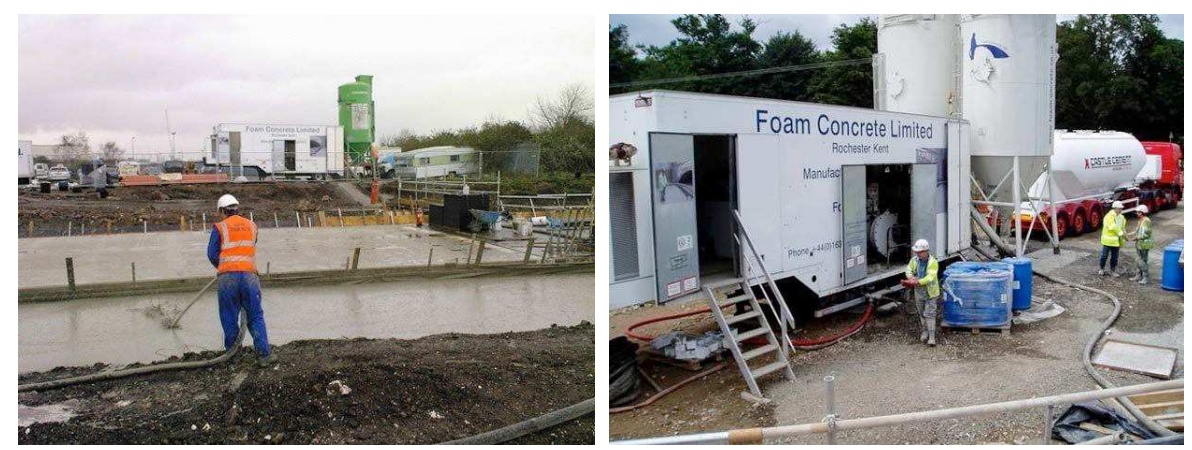

Fig. 3: Figure 1 Pumping foam concrete and the mobile device to produce a mixture [4]. 


\section{The testing experiment equipment of SvF UNIZA}

The Testing Experiment Equipment from Faculty of Civil Engineering at Žilina University (TEE FCE UNIZA) has been designed to replace the traditional layer sub-base new mixture Poroflow 17-5. TEE FCE UNIZA was built in 2012 - 2015. The subbase consists of original soil - clay of medium plasticity F6-Cl with optimal moisture content of $15.1 \%$ (Figure 4).
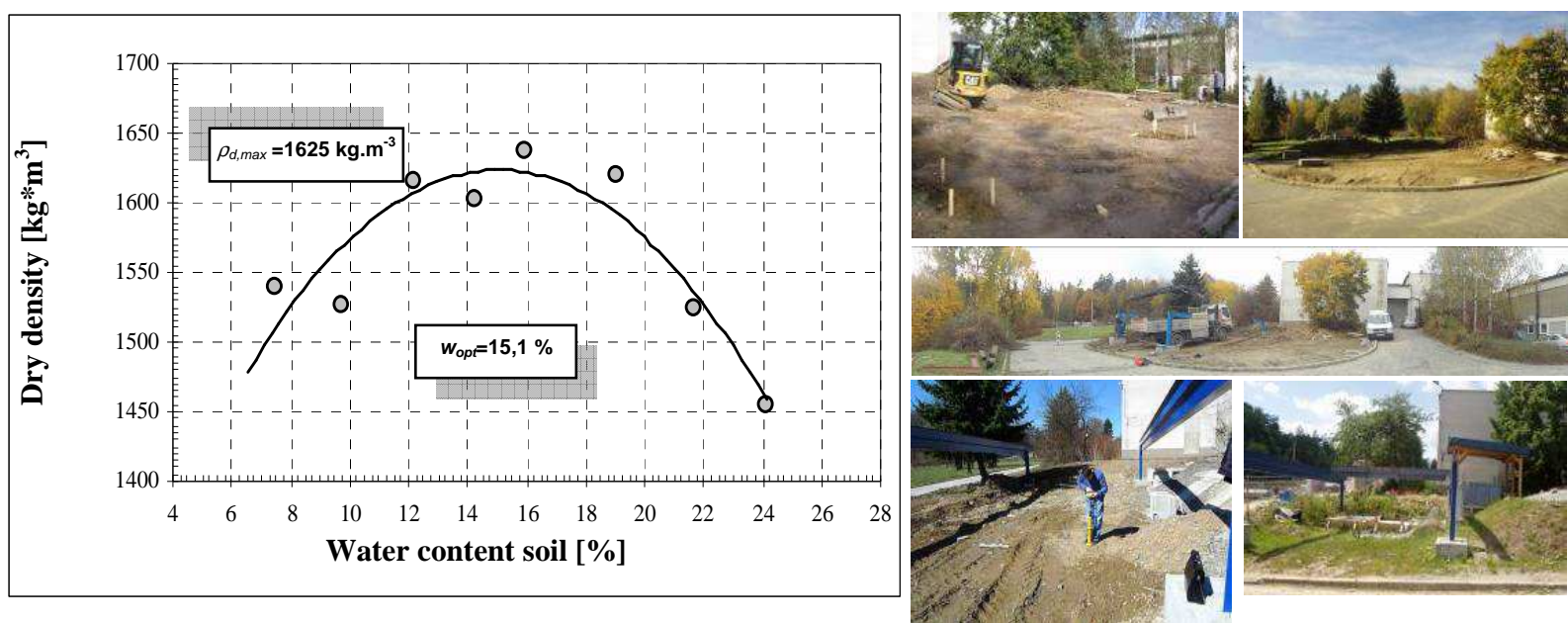

Fig. 4: Graphical evaluation of Proctor modified testing procedure and the construction of TEE FCE UNIZA.

During the research in collaboration with a foam concrete expert Ing. Walter Scherfel was built an engineering structure within TEE FCE UNIZA as can be seen in Figure 5. The building construction represents a physical homomorphic model [5] that is identical to the corresponding theory in all structural features.

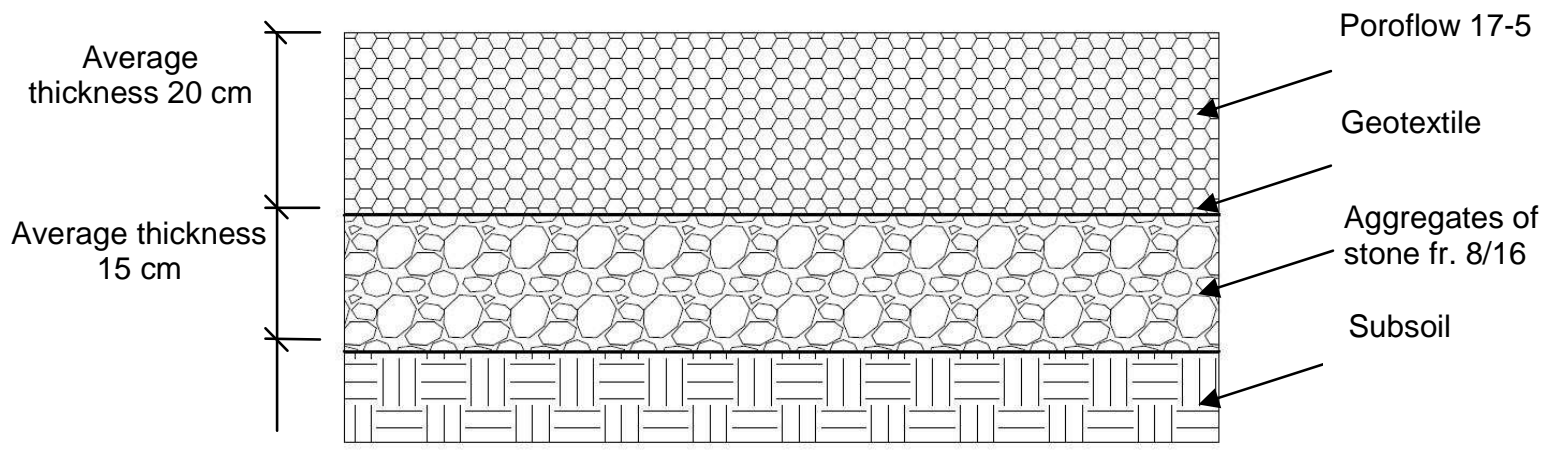

Fig. 5: Structural composition of the underlay construction using Poroflow 17-5.

Depicted structure is $6 \mathrm{~m}$ wide and $4 \mathrm{~m}$ long (Figure 6 ) in its ground plan. It is divided into three sections with a width of $2 \mathrm{~m}$, in each section there are other types of geotextiles.
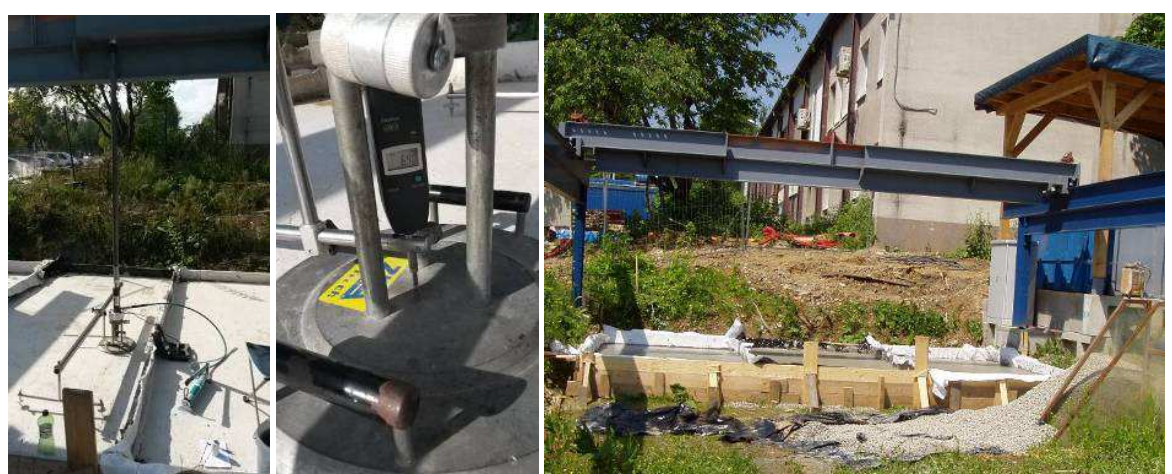

Fig. 6: Measuring system TEE (left) and view of the device examining the sag in the middle of the board (center) and view of the experimental field (right). 


\section{In situ verification of dependence of elastic modulus on bulk density of Poroflow}

Figure 7 presents dependence of elasticity modulus $E$ of lightweight concrete Poroflow on its bulk density discovered collectively under the leadership of Ing. Walter Scherfel in the laboratory. It is clear from Figure 7, that the increasing bulk density is followed by an increase of the elasticity modulus.

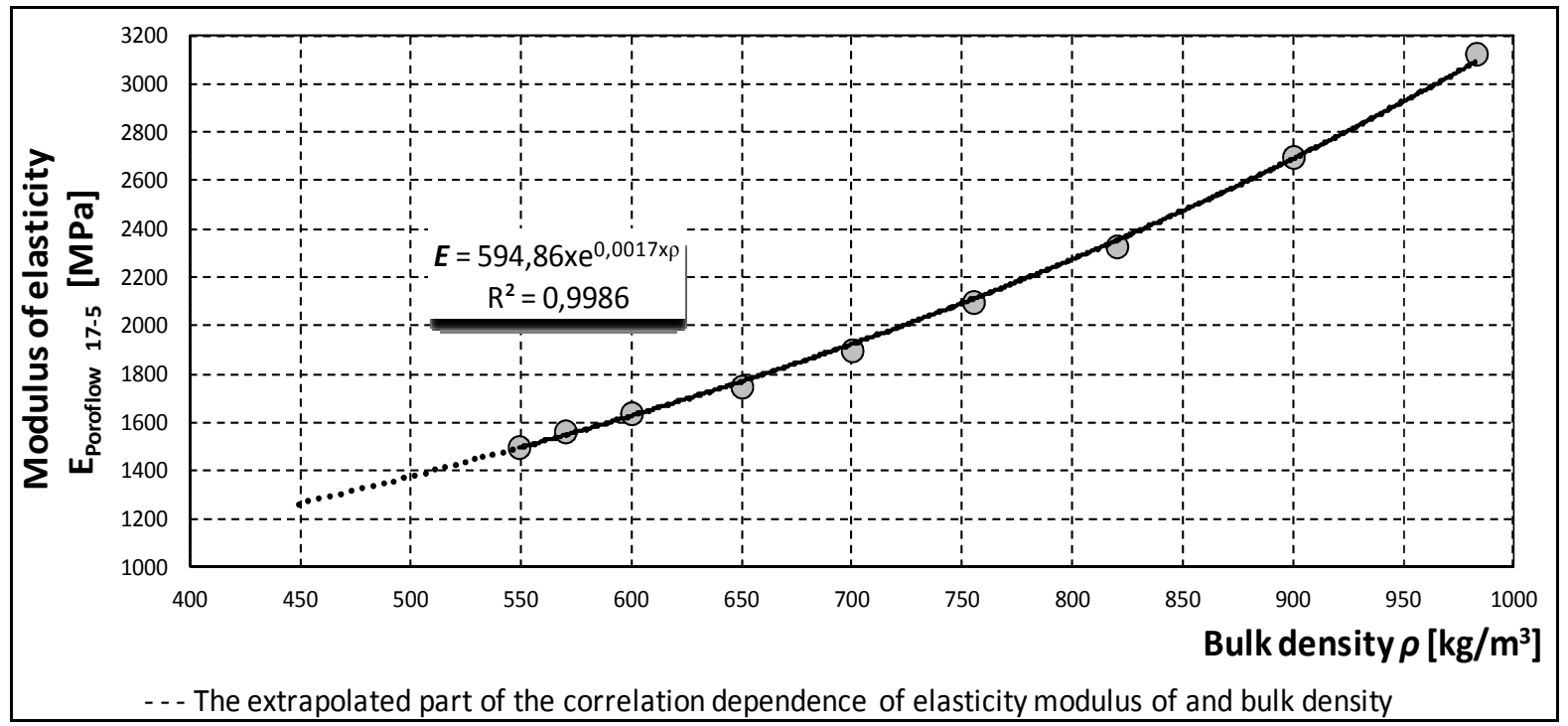

Fig. 7: Correlation dependence of elastic modulus applications Poroflow on its bulk density.

In situ verification of in labo objectified correlation dependence was performed on a physical model of homomorphic. Interest verification was based on the results of static load test (SLT) measurements according to the principles of STN 736190 [6], but also respecting to the provisions of Annex F STN 736133 [7]. The edge of the board should be away from the counterweight supports at least 2.5 times the diameter of the board. Loading board is assembled to the smooth compact surface layer and with at least two rotations around the axis small imperfections will be adjusted. As long as smaller depressions remain under the board, they will be filled with smooth sand. With the exact determination of the deformation or elasticity, it is necessary to indicate from which loading cycle relevant modules were set. Calculation principle is evident from Figure 8.

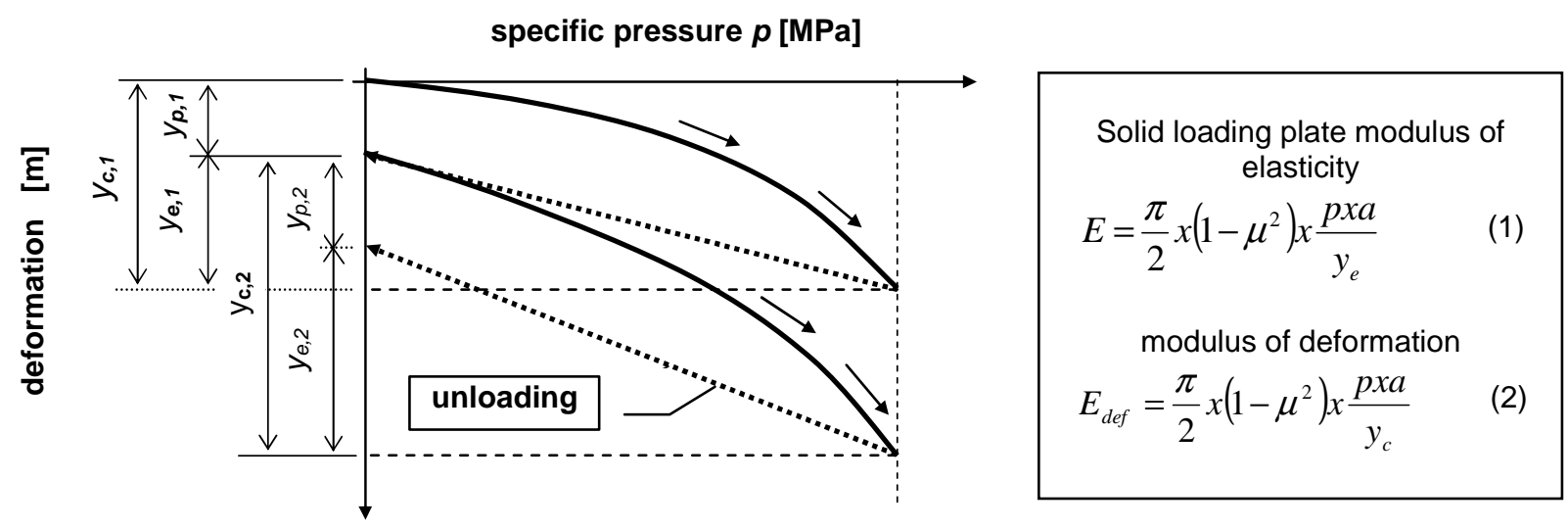

Fig. 8: The principle of calculation of the modulus of elasticity and modulus of deformation according to STN. 

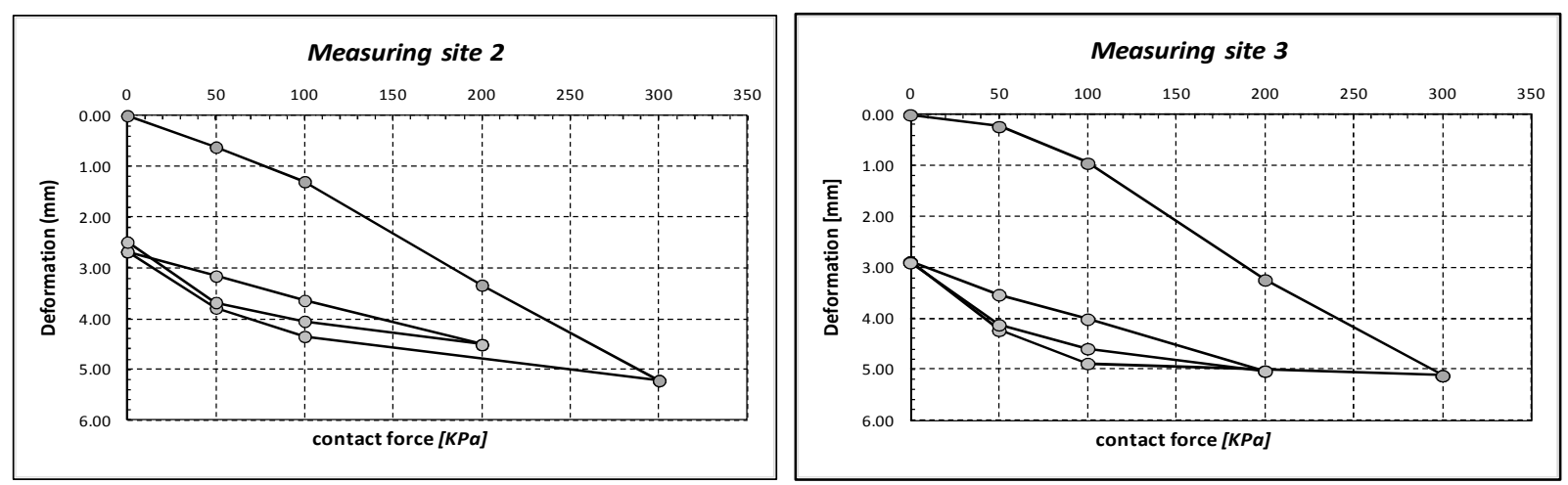

Fig. 9: The graphic recording of measurements on the surface of Poroflow 17-5 using two SLT.

Figure 9 presents a graph of two SLT measurements, which have been measured on the Testing Experimental Equipment (TEE) FCE UNIZA. Geotextile $500 \mathrm{~g} / \mathrm{m}^{2}$ was used at the measuring position 3 and separation foil was used at the measuring position 2 (see Figure 12).

In (8) was presented the correlation dependence between SLT measurements and LDD 100 device. The measurements of deformation characteristics were executed on various materials and construction layers of roads. On Figure 10 you can find the presented power correlation dependence.

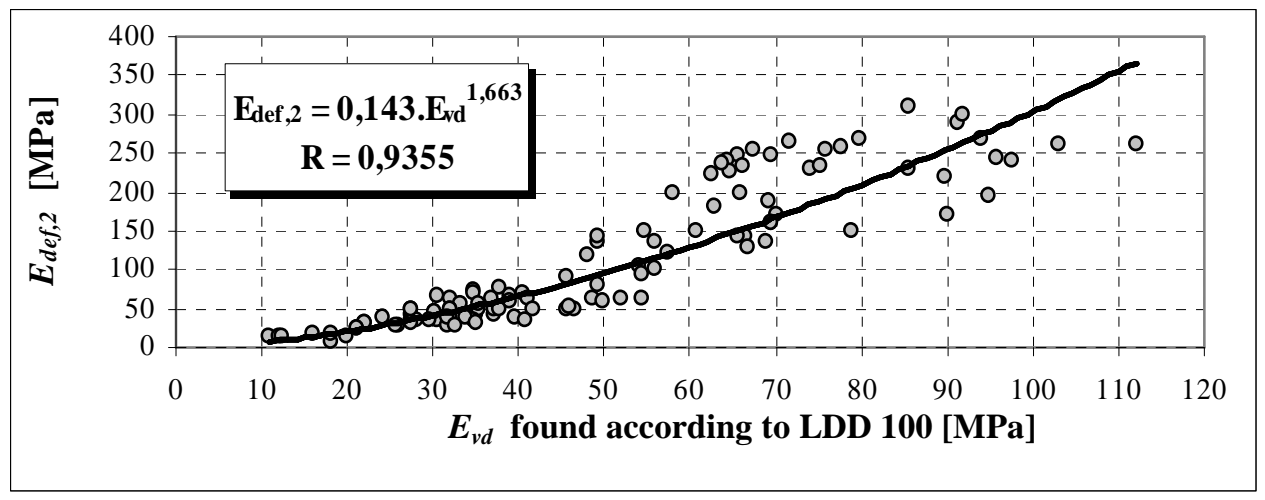

Fig. 10: A power correlation dependence of modulus of the second loading cycle $E_{d e f, 2}$ on module of deformation $E_{v d}$ measured using device LDD 100.

In Fig. 11 can be found linear dependence $E_{d e f, 2}$ by $E_{2}$ presented in Article [9]. The measurements of deformation characteristics were made on different materials, especially: clay, sand, and mixed soil.

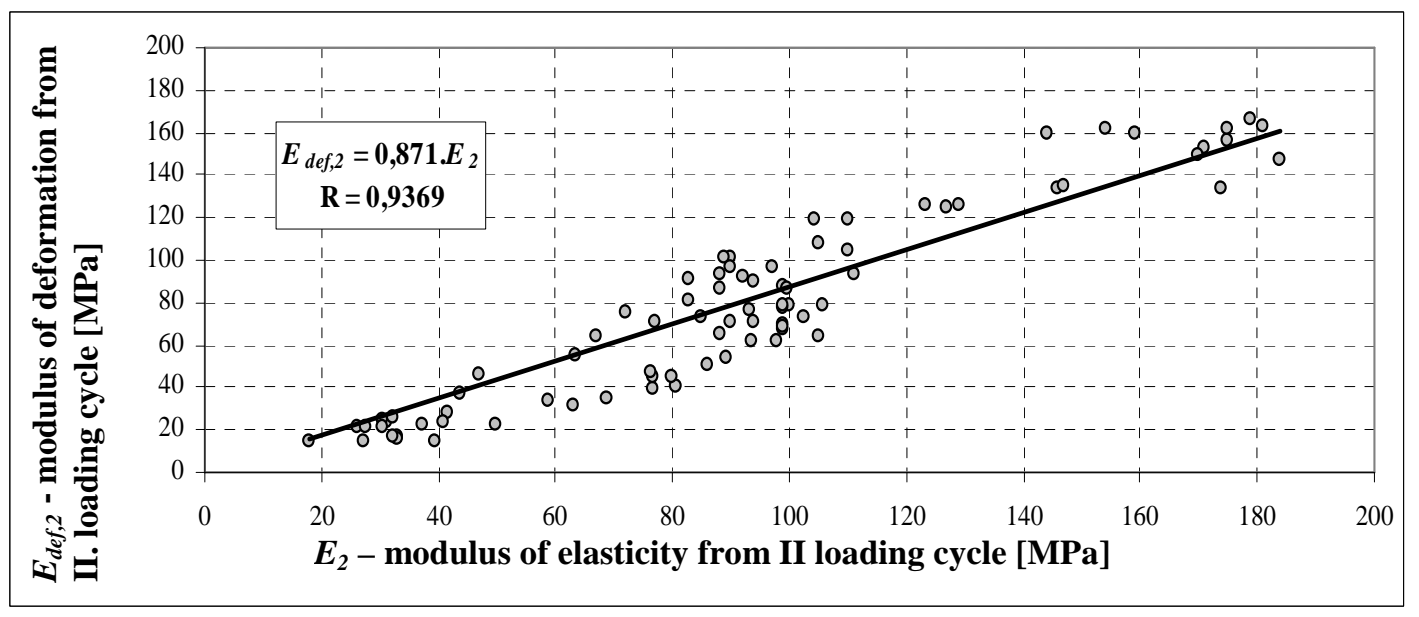

Fig. 11: The linear dependence of modulus of deformation of the second loading cycle $E_{d e f, 2}$ on the modulus of elasticity of the second loading cycle $E_{2}$. 
To determine the resident modulus of the surface layer Poroflow 17-5 to serve as a substitute for traditional sub-base, was used the SLT designed as seen in Figure 6. For the theoretical calculations in highway construction we need to know the resident modulus of individual construction layers, therefore it was necessary to recalculate the equivalent resident modulus on the surface of construction system to the modulus of elasticity layer Proroflow 17-5. This recalculation was executed with the use of SOJUZDORNII theory. The calculation model SOJUZDORNII is designed based on the equal deformation of the road homogeneous materials (attributes are same as those of the subbase) and strain two-tier system of modules $E_{l}$ (top layer thickness $h_{l}$ ) and $E_{p}$ (elastic modulus of surface or subsoil). Two-layer system is loaded by a load ring with a diameter $d$. Equivalent module of the twolayer system $E_{e}$ is calculated as below,

$$
E_{e}=\frac{E_{1}}{n^{2,5} x\left[1-\frac{2}{\pi} x\left(1-\frac{1}{n^{3,5}}\right) \operatorname{xarctg}\left(\frac{h_{1}}{d} x n\right)\right]}
$$

where in addition to the already explained symbols is:

$$
n=\sqrt[2,5]{E_{1} / E_{p}} .
$$

According to the fact that it was not possible to use the results of SLT on surface of the drainage layer (aggregates fr. 8/16), interest resident modulus were ascertained by calculation from the measurements devices LDD 100. The recalculation was carried out according to earlier mentioned correlation relations. Because the resident modulus determined from the first gel loading cycle SLT $E_{1}$ are practically identical to the resident modulus from second gel loading cycle SLT $E_{2}$, in the article [8] was identified a difference of $1.4 \%$, the elastic modulus will be referred as $E$. Based on the above and the equations in Figure 10 and 11 we will receive the equation for determination of the resident modulus from $E_{d e f, 2}$ values appointed by LDD 100 equipment.

$$
E=0,164 x E_{v d}^{1,663}
$$

As an example of the resident modulus Poroflow 17-5 SLT calculation, we refer to the evaluation of the measuring position 2 . On the Poroflow surface was rated equivalent resident modulus $E_{k v}=26.0 \mathrm{MPa}$.
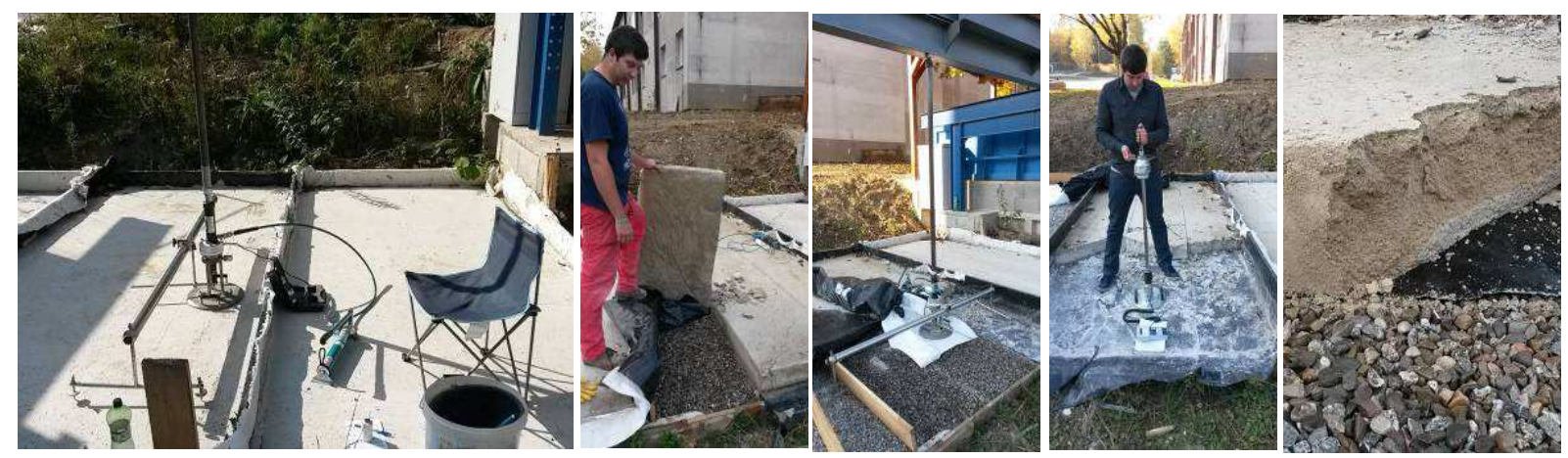

Fig. 12: Views of measurement SLT surface Poroflow 17-5, the removal of the structural system, SLT measurement and dynamic test equipment LDD 100 to the drainage layer.

To determine the exact resident modulus $E_{\text {Poroflow }}$ from in situ measurements, we need to know the resident modulus of the base system, in our case the drainage layer $20 \mathrm{~cm}$ thick, fr. 8.16 on clay subsoil. Results of SLT could not be used because of the aggregate sideways deflection, deformation of formwork or formwork decreases. Declines in the measurement frame. For this reason, with the help of LDD100 device we assigned value $E_{v d}=10.1 \mathrm{MPa}$ which we recalculated afterwards using the Equation 5 to the resident modulus of the structural supporting layer Poroflow $E_{\text {podklad, }}$ Poroflow $=7.7$ $\mathrm{MPa}$. From these values we determined value rounded to $10 \mathrm{MPa} E_{\text {poroflow }}=1580 \mathrm{MPa}$ with SOJUZDORNII method using the iterative application relationships 4 and 5 for the measured thickness of the drainage layer of $20 \mathrm{~cm}$. 


\section{Conclusions}

The article describes the latest research activities carried out by FCE UNIZA in cooperation with Ing. Walter Scherfel for the field of possibilities of using foam concrete in road construction. Specifically, outputs in situ verification in lab objectified correlation dependence resident modulus of foam concrete Poroflow by its bulk density. Objectification in question was performed on physical models of homomorphic transport system in the building design according to Figure 5, 6, 12, and used concrete was Poroflow 17-5. For objectification in labo depending Poroflow resident modulus of the bulk density (Figure 7) was for its bulk density of $500 \mathrm{~kg} / \mathrm{m}^{3}$ extrapolated value $E_{\text {Poroflow }} 17-5$, in lab = $1300 \mathrm{MPa}$.

Results of modulus of elasticity Poroflow 17-5 determined from recalculations of results of static and dynamic load tests measurements on all layers of the experimental design for the transportation structures are presented in Chart 1 . The average value when rounded to tens of MPa reached $E_{\text {poroflow }} 17-5$, in-situ $=1720 \mathrm{MPa}$. Elevated levels $E_{\text {Poroflow }} 17-5$, in-situ compared with $E_{\text {Poroflow }} 17-5$, in lab is explained by the effect of reinforcing geotextiles. In the standard STN 736114 (Pavement of Roads Basic Provision for structural design) show the values of modulus of elasticity sub-base layer $\mathrm{CBGM} \mathrm{C}_{5 / 6}=1500 \mathrm{MPa}$. In our case, the layer Poroflow 17-5 can be used as a substitute layers CBGM $\mathrm{C}_{5 / 6}$, because they are similar the modulus of elasticity. Currently, the research activities to optimize the structural composition for civil engineering works are in progress, including the selection of the optimal type of geotextile using which would be reached the highest values of interest of mechanical characteristics and particularly the modulus of elasticity and tensile strength in bending.

Table 1: Values of modulus of elasticity of Poroflow $17-5$, detected by reversal calculation from equivalent modulus of elasticity, measured by the SZS on the surface of Poroflow and elastic modulus of the underlay system $E_{\text {podklad, Poroflow. }}$.

\begin{tabular}{|c|c|c|c|c|c|c|c|c|}
\hline \multicolumn{9}{|c|}{$\begin{array}{l}\text { Values of modulus of elasticity of Poroflow } 17-5[\mathrm{MPa}] \text { detected by reversal calculation from equivalent } \\
\text { modulus of elasticity measured by the SZS using known values } E_{\text {podklad, }} \text { Poroflow } \\
\text { (values in MPa in parenthesis) }\end{array}$} \\
\hline \multicolumn{2}{|l|}{ Layer } & \multirow{2}{*}{$\begin{array}{l}\text { Measuring } \\
\text { position } \\
\text { M2 }\end{array}$} & \multicolumn{2}{|l|}{ Layer } & \multirow{2}{*}{$\begin{array}{l}\text { Measuring } \\
\text { position } \\
\text { M2 }\end{array}$} & \multicolumn{2}{|l|}{ Layer } & \multirow{2}{*}{$\begin{array}{l}\text { Measuring } \\
\text { position } \\
\text { M3 }\end{array}$} \\
\hline Label & $\begin{array}{l}\text { Thick } \\
\text { ness }\end{array}$ & & Label & $\begin{array}{l}\text { Thick } \\
\text { ness }\end{array}$ & & Label & \begin{tabular}{|l|} 
Thick \\
ness
\end{tabular} & \\
\hline Poroflow 17-5 & $\begin{array}{l}20 \\
\mathrm{~cm}\end{array}$ & \multirow{3}{*}{$1770 \mathrm{MPa}$} & Poroflow 17-5 & $\begin{array}{l}20 \\
\mathrm{~cm}\end{array}$ & \multirow{3}{*}{1450} & Poroflow 17-5 & $\begin{array}{l}20 \\
\mathrm{~cm}\end{array}$ & \multirow{3}{*}{$\begin{array}{r}1950 \\
(23.6 \mathrm{MPa})\end{array}$} \\
\hline \multicolumn{2}{|c|}{ Geotextile $250 \mathrm{~g} / \mathrm{m} 2$} & & \multicolumn{2}{|c|}{ Separation foil } & & \multicolumn{2}{|c|}{ Geotextile 500 g/m2 } & \\
\hline $\begin{array}{l}\text { Aggregates of } \\
\text { stones fr. } 8 / 16\end{array}$ & $\begin{array}{l}15 \\
\mathrm{~cm}\end{array}$ & & $\begin{array}{l}\text { Aggregates of } \\
\text { stones fr. } 8 / 16\end{array}$ & $\begin{array}{l}15 \\
\mathrm{~cm}\end{array}$ & & $\begin{array}{l}\text { Aggregates of } \\
\text { stones fr. } 8 / 16\end{array}$ & $\begin{array}{l}15 \\
\mathrm{~cm}\end{array}$ & \\
\hline \multicolumn{2}{|c|}{ Geotextile $250 \mathrm{~g} / \mathrm{m} 2$} & & \multicolumn{2}{|c|}{ Geotextile $250 \mathrm{~g} / \mathrm{m} 2$} & & \multicolumn{2}{|c|}{ Geotextile $250 \mathrm{~g} / \mathrm{m} 2$} & \\
\hline \multicolumn{9}{|c|}{ Clay subsoil with optimal moisture $w_{\text {opt }}=15.1 \%$ a $\rho_{d, \max }=1625 \mathrm{~kg} / \mathrm{m} 3$} \\
\hline
\end{tabular}




\section{Acknowledgement}

This contribution is the result of the project implementation: "Support of the Research and Development for Centre of Excellence in Transport Engineering" (ITMS: 26220120031) supported by the Research \& Development Operational Programme funded by the ERDF.

\section{References}

[1] MARCUS VITRUVIUS POLLIO: Deset knih o architektuře. Preklad Alois Otoupalík, Arista 2001. ISBN 80-86410-23-4.

[2] Sedmesát divů světa : Osudy slavných stavebních památek. Uspořádal Chris Scaree. Nakladatelství Slovart 2000, s. 304. ISBN 80-7209-711-3.

[3] DECKÝ, M. a kol.: Mechanika vozoviek pozemných komunikácií. Vysokoškolská učebnica. EDIS - vydavatel'stvo Žilinskej univerzity 2014. Prvé vydanie, s. 494. ISBN 978-80-554-0934-4.

[4] MACOŠíNEC, P.: Možnosti využitia l'ahkých betónov v konštrukčných vrstvách vozoviek a spevnených plôch pre statickú dopravu. Diplomová práca. Katedra cestného stavitel'stva, Stavebná fakulta, Žilinská univerzita v Žiline, 2015.

[5] DECKÝ, M.: Systémové modelovanie - účinný nástroj výskumu vozoviek. In: 6. seminár s medzinárodnou účast’ou Q-2004 - Technológie údržby ciest. Žilina, 27. - 28. apríl 2004, s.168 171. ISBN 80-8070-233-0.

[6] STN 736190 Statická zat’ažovacia skúška podložia a podkladových vrstiev vozoviek, 1980.

[7] STN 736133 Stavba ciest. Teleso pozemných komunikácií, 2010.

[8] ZGUTOVÁ, K. - DECKÝ, M. - PITOŇÁK, M.: Kontrola kvality zhutnenia zemných konštrukcií dopravných stavieb. In: Silničný obzor. 2001, roč. 72, č. 4, s. 101 - 108. ISSN 0322-7154. 